\title{
The Era of Omics and Personalized Medicine
}

\author{
Eugen-Matthias Strehle* \\ Honorary Consultant in Neuromuscular Genetics, Institute of Genetic Medicine, UK
}

Submission: February 16, 2017; Published: February 17, 2017

*Corresponding author: Eugen-Matthias Strehle, Honorary Consultant in Neuromuscular Genetics, Institute of Genetic Medicine, Newcastle, Consultant Pediatrician, Northumbria Healthcare NHS Foundation Trust, Cramlington, Associate Clinical Lecturer, Medical School, Newcastle University, UK, Email: strehle@doctors.org.uk

\section{Editorial}

We live in politically and scientifically eventful and interesting times. The umbrella term 'omics' is frequently used by scientists and physicians, and refers to the subjects of genomics (study of all human genes), proteomics (study of all human proteins) and metabolomics (study of all human metabolites). Watson and Crick provided the basis for these emerging scientific fields by deciphering the genetic code and by reproducing the molecular structure of DNA [1]. Jacob and Monod invented the biological principle of 'DNA makes RNA makes protein' which is still valid today [2]. Both research teams received the Nobel Prize for their achievements. Sickle cell anemia, which is caused by a genetic defect in the hemoglobin subunits, was one of the first diseases to be understood at the molecular level [3].

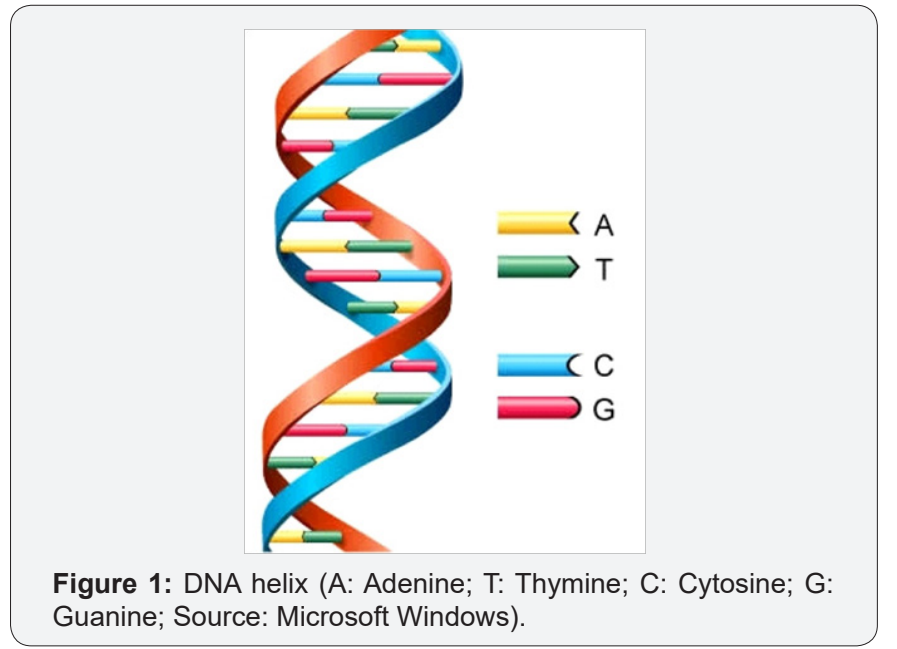

The Human Genome project was launched in the United States in 1990 and completed in 2006 at an estimated cost of 3 billion US dollars. The human genome consists of ca. 3 billion base pairs and ca. 20,000 genes which encode over 200,000 proteins. The total number of different human metabolites has not been determined accurately. Only ca. $1 \%$ of the human genome contains coding regions (exons), the remaining ca. 99\% are non-coding regions (introns), the function of which is largely unknown. The latest development in the field of genetics is next generation sequencing (NGS), also called massive parallel sequencing. The workflow in NGS involves the following steps: 1. Extraction of DNA from a blood sample and fragmentation. Ligation of DNA fragments with adaptors specific to sequencing platform. Attachment of DNA molecules to solid phase (e.g. glass slide) [4]. Amplification of DNA fragments with the polymerase chain reaction (PCR) [5]. Sequencing by synthesis using 4 fluorescently labelled nucleotides (Figure 1) [6]. Laser excitation and photographic capture of fluorescent nucleotides (base calling). With modern technology (e.g. Illumina or Ion Torrent), the entire genome of one patient can be sequenced in 1 day for 1000 US dollars [4]. In 2013, the Secretary of State for Health in the United Kingdom and Genomics England announced the 100,000 Genome Project. The objective of this nationwide study is the sequencing of 100,000 genomes from patients with rare diseases and cancers (and their relatives) treated by the National Health Service (NHS, 5). In parallel, Health Education England, a non-departmental public body, has rolled out a sponsored Master's Programme in Genomics Medicine for NHS employees. This part-time course leading to a Master's degree over 2 years is offered by 5 English universities (Birmingham, Exeter, London x 2, Newcastle). It includes 8 modules covering subjects such as omics technologies, pharmacogenomics, and genomics of infectious and rare disease, and cancer; and a small research project [6]. The objective of this programme is the introduction of NHS staff to the emerging techniques and applications of NGS which are likely become clinically relevant in future. Massive parallel sequencing is an essential part of P4 medicine (predictive, preventive, personalized and participatory). P4 medicine aims to timely diagnose illness with high accuracy and provide effective treatment tailored to the needs of the individual patient [7]. It remains to be seen whether these exciting new developments in medicine are affordable to the NHS and other health services abroad. 


\section{References}

1. Watson JD, Crick FH (1953) Molecular structure of nucleic acids: structure for deoxyribose nucleic acid. Nature 171: 737-738.

2. Buc H (2016) Francois Jacob, André Lwoff and Jacques Monod, fifty years after the Nobel Prize. Res Microbiol 167(3): 155-158.

3. Meier ER, Fasano RM, Levett PR (2017) A systematic review of the literature for severity predictors in children with sickle cell anaemia Blood Cells Mol Dis.
4. Strachan T, Goodship J, Chinnery P (2015) Genetics and Genomics in Medicine. Garland Science, New York, USA.

5. Genomics England.

6. Health Education England.

7. De Bellis M, Camerino DC, Desaphy JF (2017) Toward precision medicine in myotonic syndromes. Oncotarget.

\section{Your next submission with Juniper Publishers} will reach you the below assets

- Quality Editorial service

- Swift Peer Review

- Reprints availability

- E-prints Service

- Manuscript Podcast for convenient understanding

- Global attainment for your research

- Manuscript accessibility in different formats ( Pdf, E-pub, Full Text, Audio)

- Unceasing customer service

Track the below URL for one-step submission https://juniperpublishers.com/online-submission.php 